\title{
Antifungal Activity of Forty Higher Plants against Phytopathogenic Fungi
}

\author{
Jaripa Begum ${ }^{1}$, Mohammad Yusuf ${ }^{1}$, Jashim Uddin Chowdhury ${ }^{1}$, Saifulla Khan ${ }^{1}$ and M Nural Anwar²* \\ ${ }^{1}$ Bangladesh Council of Scientific \& Industrial Research (BCSIR) Laboratories, Chittagong, Chittagong 4220, Bangladesh, ${ }^{2}$ Department of \\ Microbiology, University of Chittagong, Chittagong 4331, Bangladesh
}

[Received 10 December 2006; Accepted 21 April 2007]

\begin{abstract}
Ethanolic extract of $\mathbf{4 0}$ higher plants representing 23 families were tested for antifungal activity against some phytopathogenic fungi. The two most active plants showing potent antifungal activity were Acorus calamus and Piper betel. The rhizome extract of $A$. calamus exhibited highest antifungal activity inhibiting the mycelial growth completely $(100 \%)$ against all the 6 test pathogens. P. betel exhibited more than $50 \%$ inhibition against most of the test fungi. The ethanolic extract of several higher plants could be used as alternative source of antifungal agents for protection of plants or crops against fungal infection.
\end{abstract}

Keywords: Antifungal activity, Phytopathogenic fungi, Higher plants

Every year a lot of crop damage is caused by various diseases and among them fungal diseases are very common ${ }^{1-2}$. Although the use of synthetic fungicides in plant disease control have shown its fruitfulness in the improvement of agriculture, several of these have been found to display side-effects in the form of carcinogenicity, detrimental effects and other residual toxicities. The alternative choice therefore would be the use of botanical fungicides, which are advocated to be largely non-phytotoxic, systematic and easily biodegradable in nature ${ }^{2-3}$.

It is believed that antimicrobial agents are present in higher plants. Some recent researches on antifungal activity of extracts of several higher plants have indicated the possibility of their exploitation as natural antifungal agents for control of plant diseases ${ }^{1,4-8}$ but as yet little has been known in this field.

So, an attempt has been made to search the higher plants of Bangladesh for active antifungal agent, which may be useful therapeutically against the fungal diseases of crops prevalent in the country.

The plant materials (whole plant, aerial parts, leaf, root, bark and rhizome) were collected fresh from various localities in Chittagong, Cox's Bazar, Rangamati and Moheshkhali areas and were identified by one of us. A set of voucher herbarium specimens was made for each collection and these vouchers have been preserved in the herbarium Bangladesh Council of Scientific and Industrial Research (BCSIR) Laboratories, Chittagong. Plant materials were cut into small pieces $(1-2 \mathrm{~cm})$, air-dried, powdered mechanically and extracted with $80 \%$ ethanol. The extracts were filtered and concentrated to near dryness under reduced pressure and low temperature $\left(40^{\circ}-50^{\circ} \mathrm{C}\right)$ with the help of rotary vacuum evaporator. In vitro antifungal activity of the extract was done by poisoned food technique ${ }^{9}$. Potato dextrose agar (PDA) medium was used for the culture of fungi. Each extract was redissolved in specific volume of absolute ehanol and mixed with sterilized melted PDA medium to obtain the desired concentration $(1 \mathrm{mg} / \mathrm{ml}$.) and this was poured in sterilized petriplates $(20 \mathrm{ml} / \mathrm{plate})$. At the center of each Petri plate 5-days-old fungal mycelial block (5 $\mathrm{mm}$ in diametre) was inoculated, which was subsequently incubated at $25^{\circ} \pm 1^{\circ} \mathrm{C}$. The diameter of each fungal colony was measured after 3-5 days of incubation. Nystatin $(100 \mu \mathrm{g} / \mathrm{ml})$ was used as a standard antifungal drug for comparison of results under identical conditions. The percent of mycelial growth inhibition of the test fungus was calculated as described earlier ${ }^{10}$.

The results of in vitro antifungal activity of ethanolic extract of 40 higher plants belonging to 23 families are summarized in Table 1 . Plant extracts that inhibited more than $50 \%$ of the normal growth were considered as effective. The degree of susceptibility varied depending on the plant species. Among the plants screened, 11 showed antifungal activity against one or more phytopathogenic fungi tested. Extract of Hedychium thyrsiformae, Clerodendrum viscosum and Zingiber zerumbet were found effective only against Botryodiplodia theobromae showing more than 50\% inhibition. Extracts of Dalbergia sisoo was found effective against Fusarium equiseti (ca. 52\%) and Colletrotrichum corchori (ca. 53\%); Datura metel against Macrophomina phaseolina (ca. 53\%) and B. theobromae (ca. $72 \%$ ). Inhibition of mycelial growth ( $>50 \%$ ) was also obtained with the extract of Eupatorium odoratum against M. phaseolina (ca. 74\%) B. theobromae (ca. 66\%) and C. corchori (ca. 52\%); Hyptis suaveolens against Alternaria alternata (ca. 53\%), Curvularia lunata (ca. 54\%) and B. theobromae (ca. 61\%); Vitex negundo against F. equiseti (ca. 54\%), B. theobromae (ca. 58\%) and C. corchori (ca. 52\%).

* Corresponding author:

Dr. $M$ Nural Anwar, Professor, Department of Microbiology, University of Chittagong, Chittagong 4331, Bangladesh

Tel (Office): (031) 682031-39/4464; Tel (Home): (031) 681688; Fax: +880 (031) 726310; E-mail: anwarmn54@yahoo.com 
Table 1. Antifungal activities of the extracts 40 higher plants against 6 phytopathogenic fungi

\begin{tabular}{|c|c|c|c|c|c|c|c|}
\hline \multirow[t]{2}{*}{ Plant (Family) } & \multirow[t]{2}{*}{ Plant part } & \multicolumn{6}{|c|}{ Percent radial mycelial growth inhibition } \\
\hline & & AA & $\mathrm{CL}$ & $\mathrm{FE}$ & MP & BT & $\mathrm{CC}$ \\
\hline Acorus calamus (Araceae) & Rhizome & 100 & 100 & 100 & 100 & 100 & 100 \\
\hline Aeschynomene Americana (Leguminosae) & Aerial part & 3 & 2 & 17 & 7 & 19 & 13 \\
\hline Anogeissus latifolia (Combtetaceae) & Leaf & 13 & 0 & 24 & 6 & 3 & 14 \\
\hline Avicennia alba (Avicenniaceae) & Leaf & 42 & 48 & 43 & 34 & 40 & 42 \\
\hline Catharenthus roseus (Apocynaceae) & Leaf & 25 & 15 & 19 & 0 & 30 & 23 \\
\hline Citrus grandis (Rutaceae) & Leaf & 15 & 0 & 10 & 7 & 1 & 10 \\
\hline Cissus repens (Vitacear) & Aerial part & 8 & 0 & 0 & 26 & 0 & 0 \\
\hline Clerodendrum viscosum (Verbenaceae) & Leaf & 34 & 24 & 11 & 39 & 59 & 11 \\
\hline Cymbopogon flexuosus (Gramineae) & Leaf & 29 & 16 & 25 & 20 & 13 & 30 \\
\hline Cymbopogon osmastonii (Gramineae) & Leaf & 24 & 22 & 19 & 17 & 38 & 27 \\
\hline Eupatorium odoratum (Compositae) & Leaf & 48 & 41 & 44 & 74 & 66 & 52 \\
\hline Eupatorium triplinerve (Compositae) & Aerial part & 32 & 39 & 39 & 24 & 27 & 38 \\
\hline Garcinia cowa (Guttiferae) & Leaf & 11 & 2 & 0 & 18 & 17 & 0 \\
\hline Hedychium thyrsiforme (Zingiberaceae) & Leaf & 34 & 36 & 34 & 35 & 56 & 39 \\
\hline Hedyotis corymbosa (Rubiaceae) & Whole plant & 22 & 18 & 15 & 12 & 37 & 26 \\
\hline Hyptis suaveolens (Labiatae) & Leaf & 53 & 54 & 40 & 47 & 61 & 22 \\
\hline Lantana camara (Verbenaceae) & Leaf & 21 & 18 & 13 & 0 & 44 & 28 \\
\hline Lawsonia inermis (Lythraceae) & Leaf & 12 & 8 & 31 & 18 & 15 & 30 \\
\hline Lippa javanica (Verbenaceae) & Leaf & 20 & 18 & 33 & 19 & 37 & 28 \\
\hline Litsea glutinosa (Lauraceae) & Leaf & 22 & 11 & 18 & 0 & 32 & 20 \\
\hline Melastoma malabathricum (Melastomaceae) & Leaf & 29 & 19 & 20 & 0 & 18 & 26 \\
\hline Michelia champaca (Magnoliaceae) & Leaf & 27 & 18 & 27 & 0 & 23 & 32 \\
\hline Solanum filicifolium (Solanaceae) & Leaf & 42 & 29 & 43 & 14 & 39 & 44 \\
\hline Terminalia chebula (Combretaceae) & Leaf & 34 & 34 & 27 & 0 & 52 & 38 \\
\hline Wedelia chinensis (Compositae) & Whole plant & 20 & 11 & 19 & 0 & 11 & 24 \\
\hline Zingiber zerumbet (Zingiberraceae) & Aerial part & 48 & 40 & 44 & 24 & 58 & 42 \\
\hline Nystatin (Antifungal antibiotic) & - & 56 & 72 & 46 & 71 & 82 & 42 \\
\hline
\end{tabular}

$\mathrm{AA}=$ Alternaria alternata $; \mathrm{CL}=$ Curvularia lunata $; \mathrm{FE}=$ Fusarium equiseti $; \mathrm{MP}=$ Macrophomina phaseolina $; \mathrm{BT}=$ Botryodiplodia theobromae; $\mathrm{CC}=$ Colletrotrichum corchori

The plants that showed wide spectrum of antifungal activity were Acorus calamus and Piper betel. A. calamus exhibited highest antifungal activity inhibiting the mycelial growth completely $(100 \%)$ against all the 6 test pathogens. P. betel exhibited more than $50 \%$ inhibition against all the test pathogens except M. phaseolina (ca. 49\%).

Although the extracts from higher plants are known to control some of the plant diseases ${ }^{11-14}$, the availability of antifungal principles in plants is less compared to antibacterial and antiviral principles. According to a test report of medicinal plant project in India only 1 (Arnebia nobilis) out of about 880 plants tested exhibited antifungal activity against Candida albicans ${ }^{15}$. In another study, Anwar et al. ${ }^{7}$ reported that out of 23 plants tested for antifungal activity against 5 phytopathogenic fungi, none of them was found to be total inhibitor of the fungi tested. So, the present findings on the antifungal activity of higher plants might serve as a potential source of antifungal agents against a wide variety of pathogenic fungi.

\section{Acknowledgement}

The Authors wish to express their sincere thanks to the Ministry of Science and Information \& Communication Technology, Government of the People's Republic of Bangladesh, for providing the financial support to carry out the work. Thanks are due to Director, BCSIR Laboratories, Chittagong for his generous cooperation and encouragement. 


\section{References}

1. Naidu AD \& John VT. 1981. In vitro inhibition of rice fungal pathogens by extracts from higher plants. Int Rice Res Newsl. 6 (5): 12-14.

2. Fawcett $\mathrm{CH}$ and Spencer DM. 1970. Plant chemotherapy with natural products. Annu Rev Phytopathol. 8: 403-418.

3. Beye F. 1978. Insecticides from the vegetable Kingdom. Plant Res Dev. 7: 13-31.

4. Gundidza M. 1986. Screening of extracts from Zimbabwean higher plants: II. Antifungal properties. Fitoterapia. 57(2): 111-114.

5. Shetty SA \& Shetty HS. 1987. Control of seed borne fungal pathogens of paddy using Strychnos nux-vomica extract. Oryza. 24: 153-159.

6. Miah MAT, Ahmed HU, Sharma NR, Ali A \& Miah SA. 1990. Antifungal activity of some plant extracts. Bangladesh J Bot. 19(1): 5- 10 .

7. Anwar MN, Singa P, Begum J \& Chowdury JU. 1994. Antifungal activity of some selected plant extracts on phytopathonic fungi. Bangladesh J Life Sci. 6(2): 23-26.

8. Qureshi SM, Rai K \& Agrawal SC. 1997. In vitro evaluation of inhibitory nature of extracts of 18 plant species of chhindwara against 3 keratinophilic fungi. Hindustan Antibiot Bull. 39(1-4): 56-60.
9. Grover RK \& Moore JD. 1962. Toximetric studies of fungicides against brown rot organisms Sclerotina flucticola and S. laxa. Phytopathol. 52: $876-880$.

10. Rahman MS \& Anwar MN. 2006. Antifungal and cytotoxic activity of conessine isolated from the stem bark of Holarrhena antidysenterica. Bangladesh J Med Sci. 12(2): 116-119.

11. Khanna SGS, Nene YL, Banerjee CK \& Tapliyal PN. 1967. A note on the isolation and chemical characterization of antifungal agents from extracts of Anagallis arvensis. Indian Phytopathol. 20: 64-66.

12. Annapurna Y, Saktimitra DA, Iyengar S, Rao N \& Rao UTB. 1983. Antimirobial activity of leaf extracts of Polyalthia longifolia. Phytopathol Z. 106: 183-185.

13. Alice D \& Rao AV. 1987. Antifungal effect of plant extracts on Drechslera oryzae in rice. Int Rice Res Newsl. 12 (2): 28-30.

14. Bashar MA \& Rai B. 1991. Antifungal activity of some plant parts against Fusarium oxysporum F sp. ciceri. Bangladesh J Bot. 20(2): 219-222.

15. Banerjee AB, Gupta SK \& Roy D. 1986. Antifungal principles of Curcuma zedoaria Roscoe. J Pharmacog Res Assoc India. 7(1-2): $5-8$. 